Final-author Version (repaginated) of J. Handmaker (2020) 'Lawfare against academics and the potential of legal mobilization as counterpower', pp. 233-260 in D. Landy, R. Lentin and C. Mccarthy (Eds.) Enforcing Silence: Academic Freedom, Palestine and the Criticism of Israel (London: Zed).

\title{
Lawfare against academics and the potential of legal mobilization as counterpower
}

\section{Jeff Handmaker}

\section{BDS as Legal Mobilization 1}

On 27 April 2016, Omar Barghouti, an internationally-known and respected scholar, addressed a conference at Stanford University regarding the boycott, divestment and sanctions (BDS) movement for Palestinian rights. He explained the underpinnings of the BDS call issued by the movement in 2005 as being framed by three separate demands, each of which flowed from Palestinians' inalienable rights to self-determination, all of which were based on international law and outlined later in this chapter (BNC 2005).

During his contribution to the 2016 Stanford conference, Barghouti was not physically present. He was speaking through a Skype connection since the Israeli government had (again) refused to grant him an exit permit to leave the country. This was neither the first, nor the last attempt by the Israeli government to try and curb Barghouti's academic freedom by way of repressive, law-based measures, or lawfare. Barghouti has continually been the target of an Israeligovernment funded tarnishing unit that was designed to smear Palestinian, Israeli and international BDS advocates (Oren 2016). In addition, an Israeli government minister has publicly threatened Barghouti and other BDS advocates with "targeted civil assassination" (Zonszein 2016). This particular threat was condemned by Amnesty International (2016).

${ }_{1}$ This chapter is based initially on a talk I gave at Trinity College Dublin in September 2017. 
Final-author Version (repaginated) of J. Handmaker (2020) 'Lawfare against academics and the potential of legal mobilization as counterpower', pp. 233-260 in D. Landy, R. Lentin and C. Mccarthy (Eds.) Enforcing Silence: Academic Freedom, Palestine and the Criticism of Israel (London: Zed).

The response of Barghouti and a global network of supporters in the BDS movement has been to consistently follow a strategy of law-based, civic confrontation, serving as an important, and legitimate form of legal mobilization that has gained inspiration from the global movement to end apartheid in South Africa. As Barghouti remarked in April 2017 on the occasion of his being awarded the 2017 Gandhi Peace Award:

We had to take the South African path, so to speak, to bring Israel to account by citizens around the world, institutions around the world, civil society, getting together and taking measures that would isolate Israel academically, culturally, economically, and eventually impose sanctions on it, as was done against South Africa (Goodman 2017).

As I explain in this chapter, it is both analytically and practically useful to regard the legal content of Barghouti's talk, as well as the other case studies of BDS addressed in this chapter as forms of legal mobilization (Handmaker 2019). By analysing (international) law-based advocacy, I am cognisant of the widespread skepticism that many critical and particular decolonial legal scholars have articulated about the role and function of international law. Erakat (2019: 6) has noted this concern with particular regard to the Palestinian struggle.

There are at least two reasons to be skeptical that international law has the capacity to overcome geopolitical realities and advance the Palestinian struggle for freedom. One is the sordid origin of international law as a derivative of a colonial order ... that reifies, rather than unsettles a symnetry of rights and duties among international actors. The other is the fact that the international system lacks a global sovereign, thereby politicizing enforcement by leaving it io the discretion of states to decide when, how and whom, to punish. 
Final-author Version (repaginated) of J. Handmaker (2020) 'Lawfare against academics and the potential of legal mobilization as counterpower', pp. 233-260 in D. Landy, R. Lentin and C. Mccarthy (Eds.) Enforcing Silence: Academic Freedom, Palestine and the Criticism of Israel (London: Zed).

With specific reference to the BDS movement, Erakat warns of the risk of invoking international law in the absence of "a corresponding political programme" and hence the risk of depoliticising the Palestinian struggle "by framing it as a movement for equality". The struggle, she argues, is funadmentally "against settler-colonial dominance" (Ibid 231). Hence, campaigns that are based on a rights-based approach are not only incapable of redressing the historical dispossesion of Palestinian land and livelihoods, but situating the struggle in terms of "competing rights" without addressing the massive power differentials between settlercolonial Israelis and Palestinians who are claiming those rights (Ibid 232). Instead, Erakat argues - like other scholars of Third World Approaches to International Law or TWAIL, such as Samour (2017) and Reynolds (2017) - in favour of an historical understanding of international law and institutions in order to reimagine the potential of international law to support the Palestinian struggle.

Notwithstanding these valid concerns, much of the law-based, civic-led advocacy is highlyrefined in Israel-Palestine, where there is a significant amount of legal knowledge, and international human rights law has formed a significant role in the normative architecture. Rather than passively insisting on its enforcement, international law has been mobilized by Palestinian civic actors in a political response to what has been described as "an unmet obligation of the organized international community to resolve a conflict partially generated by its own actions" (UN 2017, iv).

It is well-documented that the Government of Israel takes a highly exceptionalist position with regard to international law, particularly with regard to Palestinian self-determination, meaning Israel only follows international law when it suits its interests (Akram et al. 2011). Just as the case during the 1980s in South Africa, which also faced global criticism of its 
Final-author Version (repaginated) of J. Handmaker (2020) 'Lawfare against academics and the potential of legal mobilization as counterpower', pp. 233-260 in D. Landy, R. Lentin and C. Mccarthy (Eds.) Enforcing Silence: Academic Freedom, Palestine and the Criticism of Israel (London: Zed).

apartheid policies, such blatant disregard for the global applicability of international law explains why appealing to international law to substantiate criticisms of Israel's treatment of Palestinians, particularly manifested through a call for BDS, has such global resonance.

This chapter proceeds as follows. In section II, I explain Israel's legal regime in which lawfare and legal mobilization are expressed. In section III, I discuss the use of law in relation to academic freedom claims, making a distinction between legal mobilization and lawfare. An analytical framework that can be used to evaluate how law is strategically used by civic actors as either legal mobilization or lawfare is not fully developed in this particular chapter, though I have explained this elsewhere (Handmaker 2019). Instead, I briefly introduce the framework and develop legal mobilization and lawfare as analytical concepts, which are then applied against various examples of law-based advocacy, either from proponents of, or objectors to the global BDS movement for Palestinian rights.

The chapter then goes on to evaluate the transformative potential of drawing on international human rights law, using legal mobilization to support a global movement for BDS aimed at ending Israel's violations of Palestinian rights under international law, and defending academics and other advocates critical of Israel against lawfare. I then analyze examples of lawfare where legal and/or policy measures have been imposed by the Israeli government against academic critics of Israel, and particularly BDS advocates to try and suppress their freedom of speech and freedom of association, which have been wielded by a range of government-linked, but mostly privately-funded lawfare organizations. This then allows me to revisit in the penultimate section, the crucial distinction between lawfare and legal mobilization and finally to draw conclusions in the final section regarding both the 
Final-author Version (repaginated) of J. Handmaker (2020) 'Lawfare against academics and the potential of legal mobilization as counterpower', pp. 233-260 in D. Landy, R. Lentin and C. Mccarthy (Eds.) Enforcing Silence: Academic Freedom, Palestine and the Criticism of Israel (London: Zed).

potential and challenges of law-based BDS advocacy to pursue a progressive social justice agenda.

But first I briefly outline the context in which both legal mobilization and lawfare take place in relation to Israel-Palestine, explaining the nature of Israel's legal regime.

\section{Israel's legal regime of apartheid}

From a normative standpoint, Israel's legal system has entrenched the socially-constructed, ethno-nationalist Jewish character of the State of Israel, which takes the form of a racialised, settler-colonial regime that is profoundly discriminatory, perhaps most visibly reinforced by the 2018 Nation-State law (Ben-Youseff and Tamari 2018). Also in its implementation, Israel's legal regime has been profoundly repressive towards Palestinians, as extensively documented, particularly regarding the situation in the occupied Palestinian territory, by organizations such as Al-Haq, B'tselem, Addameer, the Palestinian Center for Human Rights and international organizations such as Human Rights Watch, Amnesty International and Federation International Droit de l'Homme (FIDH). Hence, on a range of legal criteria, the situation in the occupied Palestinian territory can be readily described as a regime of apartheid (Dugard and Reynolds 2013; UN 2017).

Moreover, the situation of apartheid extends beyond the occupied Palestinian territory to all areas under Israeli control. Discrimination and other human rights violations in Israel have further been extensively documented by the Haifa-based Adalah Human Rights Organization, Ittijah Union of Arab Community-Based Associations and the Nazareth-based Human Rights Association. Moreover, apartheid incorporates not only legal, but also ideological, architectural and physical dimensions (Abdelnour 2013). 
Final-author Version (repaginated) of J. Handmaker (2020) 'Lawfare against academics and the potential of legal mobilization as counterpower', pp. 233-260 in D. Landy, R. Lentin and C. Mccarthy (Eds.) Enforcing Silence: Academic Freedom, Palestine and the Criticism of Israel (London: Zed).

Added to this is the also well-documented, although officially unacknowledged history that Israel's creation in 1948 was only made possible following the forcible dispossession of several hundred thousand Palestinians from their homes and lands, described by the Israeli historian Ilan Pappe (2006) as a deliberate policy of ethnic cleansing.

Confronted with such an oppressive situation, and triggered by Israel's continued building of a Wall despite the International Court of Justice declaring the Wall to be illegal, Palestinians issued the international law-based BDS Call in 2005 (Bot 2019).

\section{Pragmatic mobilization versus hegemonic instrumentalization of law}

As Barghouti specifically and the BDS movement in general have demonstrated, law can be mobilized pragmatically by civic actors, including academics in their critiques of Israel's behaviour. The concept of legal mobilization therefore refers generally to the use of law as a legitimate form of political counterpower, to underpin political claims, and more specifically as the basis for non-violent, law-based protests against oppressive regimes. As I argue in this section, legal mobilization is to be contrasted with the concept of lawfare, which refers to the hegemonic and illegitimate use of law by state and/or corporate bodies to undermine legal mobilization, including to silence dissent and to persecute individual critics of Israel.

Legal values are firmly embedded in the BDS Call (BNC 2005). The first demand of the Call is that Israel "(end) its occupation and colonization of all Arab lands and dismantl(e) the Wall" that Israel constructed in 2002, affirmed a year prior to the Call as illegal by the International Court of Justice (2004). The second demand is that Israel "recognize the fundamental rights of the Arab-Palestinian citizens of Israel to full equality", a demand 
Final-author Version (repaginated) of J. Handmaker (2020) 'Lawfare against academics and the potential of legal mobilization as counterpower', pp. 233-260 in D. Landy, R. Lentin and C. Mccarthy (Eds.) Enforcing Silence: Academic Freedom, Palestine and the Criticism of Israel (London: Zed).

for equality incorporated in numerous international legal instruments, notably the Universal Declaration of Human Rights, which was passed in the same year as Israel's creation (UN 1948). The final demand of the BDS Call is that Israel commit to "respecting, protecting and promoting the rights of Palestinian refugees to return to their homes and properties as stipulated in UN resolution 194", a cornerstone of Palestinian self-determination (UN 1949; Handmaker 2011).

Since the broad BDS Call in 2005, and through national and international legal processes, BDS advocates, including a very large global coalition of academics, have advocated for structural change using international law and especially rights-based arguments (Bisharat et al. 2018, 5). This use of law by civic actors striving for social change, or what can be broadly regarded as legal mobilization has two characteristics. Legal mobilization is a term to describe the practice of legal advocacy; it is also an analytical concept and interdisciplinary lens to understand the role of law in civic advocacy, in terms of its normative and its functional dimensions (Handmaker 2019).

An important distinction should be made between legal mobilization and other uses of law, including oppressive legal measures by a state and/or corporation, which should be conceptualized as lawfare. These two law-based concepts might both be superficially regarded as forms of legal instrumentalism on the assumption that the political character of the claim inevitably undermines the rule of law (Tamanaha 2005). However, I argue that they are fundamentally different. Indeed, understanding these distinctions is key to appreciating the legitimate use of law as a form of counterpower against the powerful, suppressive arm of a state. Beyond what legal mobilization and lawfare are as analytical concepts, it can also be analyzed how they operate. 
Final-author Version (repaginated) of J. Handmaker (2020) 'Lawfare against academics and the potential of legal mobilization as counterpower', pp. 233-260 in D. Landy, R. Lentin and C. Mccarthy (Eds.) Enforcing Silence: Academic Freedom, Palestine and the Criticism of Israel (London: Zed).

Clearly, law is used not only by civic actors such as academics critical of Israel and other advocates, but by a range of stakeholders, including lawfare groups such as Shurat HaDin, Legal Insurrection and the Brandeis Center, as discussed later in this chapter. As a practice, the legal mobilization of human rights adopts positive, legitimating and empowering forms, reinforcing the underlying social justice claims of BDS in what Hoffman $(2003,121)$ has referred to as "an indispensable rhetorical tool against any form of dominance and attempted hegemony." By contrast, lawfare takes negative, delegitimizing and oppressive forms, justifying retrogressive policies and even reinforcing the hegemonic actions of states, such as denying access to legal representation and holding accused persons without charge in the operation of Israel's military tribunals.

The strategic use of law by civic actors to advance human rights provides legal legitimacy to a political claim (legal mobilization), which Bot has argued is based on political principles of "emancipation, transformation, and civility" (Bot 2019: 16). This should be seen in contrast to the hegemonic manner in which law is instrumentalized by powerful states as well as individuals, groups and corporations to serve an oppressive agenda (lawfare). Legal mobilization as an analytical framework recognizes: first, the capacity of civic actors to challenge the state; second, that the values underpinning international human rights law can be translated by civic actors into a locally relevant context, rather than merely reproducing and transplanting these rules in a technocratic manner (Merry 2006) and third, international law's inherent structural bias is crucial in understanding the strategic potential for law-based advocacy, both in terms of the institutions against which legal mobilization is directed as well as the 
Final-author Version (repaginated) of J. Handmaker (2020) 'Lawfare against academics and the potential of legal mobilization as counterpower', pp. 233-260 in D. Landy, R. Lentin and C. Mccarthy (Eds.) Enforcing Silence: Academic Freedom, Palestine and the Criticism of Israel (London: Zed).

substantive law that forms the basis of any legal claim, including lawfare (Handmaker and Arts $2019,12)$. The third of these elements will be applied further in this chapter.

This three-dimensional framework forms an analytical basis for assessing both the legitimate potential of legal mobilization, as a lens to assess socially progressive forms of legal mobilization, also against the contrasting lens of lawfare as an oppressive instrumentalizing of law (Handmaker 2019). To illustrate the former, I next discuss how academics have used legal mobilization as a legitimate form of counterpower through their support for the Palestinian call for a boycott of Israeli academic and cultural institutions.

\section{Legal mobilization in promoting Palestinian rights and academic freedom}

Faced with few credible domestic legal remedies in Israel, Palestinians, together with some Israelis and a global network of supporters, including numerous academics and lawyers, have been compelled to mobilize international law in order to advocate for a socially progressive agenda, including academic freedom for Palestinian students and scholars. Thousands of academics around the world have answered the initial call by their Palestinian colleagues through the Palestinian Academic and Cultural Boycott Initiative (PACBI), which was released in 2004, the same year as the ICJ (2004) judgement and immediately preceding the 2005 Call referred to earlier. The BDS Call was signed by a broad-based collective of Palestinian civilsociety organizations, including political parties, trade unions and professional associations.

The BDS Call advocates that boycotts, divestment and sanctions "should be maintained until Israel meets its obligation to recognize the Palestinian people's inalienable right to selfdetermination and fully complies with the precepts of international law" (BNC 2005). 
Final-author Version (repaginated) of J. Handmaker (2020) 'Lawfare against academics and the potential of legal mobilization as counterpower', pp. 233-260 in D. Landy, R. Lentin and C. Mccarthy (Eds.) Enforcing Silence: Academic Freedom, Palestine and the Criticism of Israel (London: Zed).

This Call has been accompanied by three clear demands, each of which, it already noted, is grounded in international legal norms. Beyond the legal basis of justification, the several hundred signatories of the Call have appealed for different kinds of measures, each of a punitive, though non-violent character, which are equally grounded in international law and comprise: institutional boycotts, including academic boycotts, corporate divestment and ultimately sanctions against Israel. These forms of BDS can be analytically regarded as forms of legal mobilization.

In analyzing the BDS movement, several arguments can put forward, both with regard to the substantive content of the BDS Call and the character of the global movement, within the broader rubric of legal mobilization.

The first argument is that by drawing on international law, the legitimate normative character of the BDS call is enhanced, on the basis of individual claims enshrined in multiple sources of international law. This is confirmed by Barnette (2010), who observes that the legitimacy of the Palestinian narrative has been enhanced by high-profile UN reports, which critics of Israel often make reference to. One of the most damning of these reports, which has formed the basis for preliminary enquiries by the office of the Prosecutor of the International Criminal Court, is the Goldstone Commission's report confirming the commission of widespread violations of human rights and international humanitarian law in Gaza and the West Bank by the Israel's military during 2008/09.

The second argument is that the capacity of Palestinian civic actors to participate in international legal process has been an explicit claim of the BDS movement. This right to participate is embedded in international legal norms, deliberately mentioned in the BDS Call as a core principle of self-determination and supported by a broad social justice movement comprising a global network of advocates, including academics, based in Europe, 
Final-author Version (repaginated) of J. Handmaker (2020) 'Lawfare against academics and the potential of legal mobilization as counterpower', pp. 233-260 in D. Landy, R. Lentin and C. Mccarthy (Eds.) Enforcing Silence: Academic Freedom, Palestine and the Criticism of Israel (London: Zed).

North America, South Africa, Australia, India, Brazil, the Arab world and elsewhere. Through persistent and very vocal campaigns, the BNC leadership has become active participants in international and national law-based processes, from national legislatures to the European Union and various United Nations fora. In the BNC's frequent interactions with the media, advocates routinely reaffirm the relevance of respecting international law. Similarly, the public figures engaged by the movement have also based their arguments on the need to respect international law. One notable example is a statement in solidarity with the BNC by the wellknown theologian and South African anti-apartheid advocate Archbishop Desmond Tutu:

Many black South Africans have travelled to the occupied West Bank and have been appalled by Israeli roads built for Jewish settlers that West Bank Palestinians are denied access to, and by Jewish-only colonies built on Palestinian land in violation of international law (Tutu 2012).

Another example comes from the American civil rights author and scholar Alice Walker, who served, along with other eminent scholars and jurists, on the jury of the Russell Tribunal on Palestine (2011) that held hearings in different parts of the world concerning alleged violations of international law by Israel, including in Cape Town concerning the crime of apartheid. Numerous prominent scholars critical of Israel, including Sara Roy (2012), John Dugard (2018), John Reynolds (2017), Richard Falk (2017) and Noura Erakat (2019), to name just a few, have documented Israel's extensive violations of international law obligations.

Consistent and accurate reference to international law as a principal basis for their arguments renders these cultural icons and scholars powerful advocates of legal mobilization. Through the sustained efforts of the BDS movement and the prominent 
Final-author Version (repaginated) of J. Handmaker (2020) 'Lawfare against academics and the potential of legal mobilization as counterpower', pp. 233-260 in D. Landy, R. Lentin and C. Mccarthy (Eds.) Enforcing Silence: Academic Freedom, Palestine and the Criticism of Israel (London: Zed).

public figures who support the BNC, a wide range of activities by the State of Israel, and its numerous cultural, political, academic and other institutions, have been called into question at a global level.

The third argument is that, by forming a broad-based and grass-roots network of civic actors, the BDS movement has managed to connect with both the global context that has generated basic protective principles of international law as well as the local context in which these international norms find normative expression. In doing so, the $\mathrm{BNC}$ has been a powerful translator in reinforcing Palestinians' social justice claims, that are articulated in international human rights law. Accordingly, the $\mathrm{BNC}$ has charted a persistent, confrontational, non-violent and highly strategic course of action that Omar Barghouti (2011) terms a global struggle for Palestinian rights.

A further argument is that in making consistent reference to law-based justifications, the founders of the BDS movement strategically highlight some of the core legal biases present in international legal vocabularies, and particularly human rights enforcement institutions. This is visible in the preamble to the original BDS petition:

In light of Israel's persistent violations of international law; and

Given that, since 1948, hundreds of UN resolutions have condemned Israel's colonial and discriminatory policies as illegal and called for immediate, adequate and effective remedies; and

Given that all forms of international intervention and peace-making have until now failed to convince or force Israel to comply with humanitarian law, to respect fundamental human rights and to end its occupation and oppression of the people of Palestine (BNC 2005, emphasis added).

By consistently referencing international law in this historicised form that explicitly acknowledges Israels "persistent violations", 
Final-author Version (repaginated) of J. Handmaker (2020) 'Lawfare against academics and the potential of legal mobilization as counterpower', pp. 233-260 in D. Landy, R. Lentin and C. Mccarthy (Eds.) Enforcing Silence: Academic Freedom, Palestine and the Criticism of Israel (London: Zed).

the drafters of the BDS call have acknowledged that international law reinforces unequal power relations, notably within the academy. Moreover, human rights law possesses an inherent normative bias that, when wielded in a historically-grounded and anti-imperial manner, favors a socially progressive agenda, underpinning the threefold demands embodied in the BDS call and affirming the need to question institutional practices.

While affirming international human rights values, the drafters of the call are also skeptical of the transformative effect of human rights on the basis of legalistic explanations alone. This is what led the American Studies Association (ASA), comprising thousands of academics, to call for a boycott of Israeli academic institutions. In its call, the ASA explicitly mentions US complicity in "enabling" actions by the Israeli government and settlements as being:

in violation of international law, as well as in supporting the systematic discrimination against Palestinians, which has had documented devastating impact on the overall wellbeing, the exercise of political and human rights, the freedom of movement, and the educational opportunities of Palestinians (ASA 2013).

Consequently, the drafters of the BDS call, as well as academics and other advocates who have responded, have shifted their emphasis away from a reliance on formal legal institutions designed to enforce it, in favor of a broad-based, civic-led platform focused on advocating for the international isolation of Israel at an institutional level, until Israel complies with international law.

\section{Israel's campaign of lawfare and legal mobilization as a defence}

Legal mobilization for Palestinian rights, particularly through BDS has triggered a wellfinanced counter-campaign of lawfare 
Final-author Version (repaginated) of J. Handmaker (2020) 'Lawfare against academics and the potential of legal mobilization as counterpower', pp. 233-260 in D. Landy, R. Lentin and C. Mccarthy (Eds.) Enforcing Silence: Academic Freedom, Palestine and the Criticism of Israel (London: Zed).

waged by the state of Israel and its global supporters. Around ten years after the BDS movement was launched, the Government of Israel and its supporters began responding to nonviolent legal mobilization with a barrage of oppressive legal instruments. Adopting highlypoliticized interpretations of criminal law, civil liability and even municipal regulations in countries abroad, lawfare organizations have sought to harass, intimidate, slander and otherwise seek to harm individual scholars, activists, student organizations and companies critical of Israel. Unlike the BDS movement, which is inclusive and aimed at triggering critical political dialogue, these mostly government-sponsored measures to suppress the movement are profoundly discriminatory, aimed at politicizing and subverting the rule of law as a "political tool" (Bot 2019: 9).

Palestinian scholars such as Barghouti and Haidar Eid have been particularly affected by such lawfare measures, primarily taking the form of movement restrictions. Students have also been seriously affected by Israel's lawfare, with one Palestinian university (Birzeit) having faced repeated closures by the Israeli occupation forces since 1973, including an extended period of 1,571 days between 1988 and 1992. Critical Israeli scholars too have also been affected by Israel's lawfare. For example, there have been persistent efforts, including the use of a sham "international review process", to shut down the Department of Politics at Ben Gurion University, which has been known for the outspoken views of many faculty members (B.N. 2012). Professor Nadera Shalhoub-Kevorkian of Hebrew University of Jerusalem has been subject to years of in-faculty and external abuse, including bogus accusations from the Israeli media and the Israeli Education Minister Naftali Bennett of "anti-Semitism" (Tucker and Brand 2019).

Israel's campaign of lawfare has built on earlier legal forms of repression since the creation of the State of Israel in 1948, the 
Final-author Version (repaginated) of J. Handmaker (2020) 'Lawfare against academics and the potential of legal mobilization as counterpower', pp. 233-260 in D. Landy, R. Lentin and C. Mccarthy (Eds.) Enforcing Silence: Academic Freedom, Palestine and the Criticism of Israel (London: Zed).

establishment of which triggered an official State of Emergency that has persisted throughout its existence. Around the sixtieth anniversary of its creation, Israel sought to intensify legal and financial incentives aimed at attracting Israeli and foreign corporations. At the same time, the government has sought to protect corporate profits through a so-called anti-BDS law (Lis 2011). The law attacks freedom of expression by allowing corporations, including those profiting from business activities inside the occupied Palestinian territory (in violation of international law), to make claims for damages against individuals if it can be established that their advocacy (e.g. exposing complicity of these companies in international crimes) harms the corporation's economic interests. The anti-BDS law has been accompanied by a so-called "Loyalty Oath" law, which seeks to ensure allegiance to the "Jewish democratic state" and to ban a range of activities deemed to question it (Ananth 2013, 134).

There has been very limited opposition to such repressive measures among liberal Israeli human rights organizations, which generally lack a critical perspective and fail to listen to Palestinian organisations (Handmaker 2018), and none at all from Israel's higher education institutions. Instead, human rights have been invoked to rationalize the inequalities between Jewish settlers and Palestinians and to give the impression that Israel is a liberal, democratic state. Aharon Barak (2006), a former President of the Supreme Court of Israel and law professor at the Hebrew University of Jerusalem has adamantly maintained that there is normative equality in Israel, irrespective of religion or ethnicity. Another prominent human rights scholar, David Kretzmer (1992) has referred to the 1992 Basic Laws on Human Rights in Israel as amounting to a mini-revolution in terms of Israeli constitutional law, without fundamentally questioning its racist ideological basis. However promising these normative claims 
Final-author Version (repaginated) of J. Handmaker (2020) 'Lawfare against academics and the potential of legal mobilization as counterpower', pp. 233-260 in D. Landy, R. Lentin and C. Mccarthy (Eds.) Enforcing Silence: Academic Freedom, Palestine and the Criticism of Israel (London: Zed).

may be, functionally-speaking such claims are largely meaningless; Israel's legal regime has routinely betrayed these normative promises, particularly when measured against international law. By failing to seriously engage with the ideological character of these laws, and at best superficially engage with their functional character (generally limited to criticisms of Israel's practices in the occupied Palestinian territory, if at all), liberal human rights scholars in Israel have reinforced, and even become complicit in Israel's policy of exceptionalism and lawfare. Israel's lawfare has been followed by a string of laws in other countries, notably the United States and Britain, where publicly-financed entities have been informed that they will no longer receive state funding if they take a position in support of the Palestinian BDS movement (Hager 2016). These laws have been promoted by well-funded lawfare organizations such as the Reut Institute, pledging to challenge what they refer to as "delegitimization" and "resistance" networks critical of Israel (Ananth 2013, 130-136).

Another well-funded, pro-Israel lawfare organization is Shurat Hadin, based in Israel and exposed by Wikileaks as tied to Israeli intelligence agencies (Winstanley 2017), but operating transnationally and especially in the United States. On its website, the organization sensationally claims to be "bankrupting terrorism, one lawsuit at a time", while misleadingly suggesting that it is not they, but those engaged in legal mobilization that are engaged in lawfare, although the organization fails to substantiate this claim (Shurat HaDin 2018). Among other spectacular claims on its website, the organization declares itself to be:

dedicated to protecting the State of Israel. By defending against lawfare suits, fighting academic and economic boycotts, and challenging those who seek to delegitimize the Jewish State, 
Final-author Version (repaginated) of J. Handmaker (2020) 'Lawfare against academics and the potential of legal mobilization as counterpower', pp. 233-260 in D. Landy, R. Lentin and C. Mccarthy (Eds.) Enforcing Silence: Academic Freedom, Palestine and the Criticism of Israel (London: Zed).

Shurat HaDin is utilizing court systems around the world to go on the legal offensive against Israel's enemies (Ibid, emphasis added).

Amongst many other cases brought by Shurat Hadin was a lawsuit against an Australian

professor, Jake Lynch, regarding his support for the academic boycott. Raising wildly unsubstantiated allegations of racial discrimination, the organization called for his dismissal from the University of Sydney, although later dropped its claim, which appeared to be solely designed to intimidate and otherwise discourage academics from speaking out on BDS (Safi and Davidson 2014).

Another organization engaged in lawfare is Legal Insurrection (2018), which actively (and successfully) campaigned for the withdrawal of an employment contract that had been offered to US academic and prominent Israeli critic Stephen Salaita. Following intervention by Salaita's lawyers at the Center for Constitutional Rights, the University paid extensive compensation, but refused to reinstate its initial offer of employment (LaHood 2016). Legal Insurrection also reported the ASA to the IRS, alleging (unsuccessfully) that the ASA was not fulfilling the requirements of its tax-exempt status due to its endorsement of the academic boycott of Israel. Later, joined by another lawfare organization, the Brandeis Center, claims were filed (albeit later dismissed) against the ASA, erroneously alleging that the Association over-reached its contractual obligations to its members (Palestine Legal 2019).

\section{Legal Mobilization as a defence against Lawfare}

The cases of lawfare highlighted in this chapter are just the tip of an iceberg. There are many more examples of threats to individual academic freedom, hundreds of which have been carefully documented by the Chicago-based organization Palestine Legal, 
Final-author Version (repaginated) of J. Handmaker (2020) 'Lawfare against academics and the potential of legal mobilization as counterpower', pp. 233-260 in D. Landy, R. Lentin and C. Mccarthy (Eds.) Enforcing Silence: Academic Freedom, Palestine and the Criticism of Israel (London: Zed).

a legal services organization providing crucial support to academics, student associations and other targets of pro-Israel lawfare organizations. Faced with a growing range of lawfare attacks, there has been a need to invoke legal mobilization in defence of academic freedom, particularly in the United States where lawfare has mainly been focused. Various organizations have emerged that have taken the lead in support to academics critical of Israel, notably the Center for Constitutional Rights (CCR) - which has supported Palestine Legal - as well as the National Lawyers Guild (NLG) and American Civil Liberties Union (ACLU), primarily on the basis that BDS and scholarly critiques of Israel ought to be regarded as protected speech (Hauss 2017).

Basing arguments on US constitutional law, particularly concerning free speech and antidiscrimination provisions, and probono support to individuals and organisations who would potentially face extensive legal bills, organizations such as CCR, NLG and ACLU have brought robust legal argumentation in defence of baseless accusations and spurious legal claims made by lawfare organizations. Drawing on decades of engagement with American legal culture a highly-developed legal consciousness in relation to the use of the US Constitution and international human rights, and the local complexities of the cases they have been handling, as well as a keen awareness of how US citizens have developed a growing criticism of Israel's human rights record, CCR have been able to make quick, creative use of the law (Asmy 2018). Accordingly, CCR and other organizations have mobilized law as a shield to defend Lynch, Salaita and others against lawfare efforts to silence them and to a significant extent redress the otherwise massively unequal power-relations between a corporate and state-sponsored regime and individual activists and public interest groups. Moreover, CCR has carefully framed their statements to 
Final-author Version (repaginated) of J. Handmaker (2020) 'Lawfare against academics and the potential of legal mobilization as counterpower', pp. 233-260 in D. Landy, R. Lentin and C. Mccarthy (Eds.) Enforcing Silence: Academic Freedom, Palestine and the Criticism of Israel (London: Zed).

the media, showing they had made a strategic assessment of the positive bias embedded in international human rights law that supported their legal claims, which were able to thwart the efforts of groups who intended to silence critics of Israel as part of a well-financed campaign of lawfare.

\section{False Anti-Semitism Allegations}

One of the more recent (though somewhat exaggerated) lawfare efforts in Europe has been to define criticism of Israel as anti-Semitic and to secure official endorsement of this definition in support of bogus allegations of anti-Semitism. In the United States and Britain, antiSemitism claims that are conflated with criticisms of Israel are relatively easy to make, while in Europe there is much greater skepticism about such conflated claims, particularly within the academy.

The efforts to equate criticisms of Israel with anti-Semitism have mainly been led by a lobby group known as the International Holocaust Remembrance Alliance (IHRA), which, in its proposed definition of anti-Semitism has argued that "the targeting of the state of Israel, conceived as a Jewish collectivity" amounts to anti-Semitism (IHRA 2016). This wide formulation makes it practically impossible to challenge the Jewish character of the State of Israel, parroting a position that the Supreme Court of Israel has routinely affirmed, and the Nation-State Law of 2018 has entrenched at the legislative and executive levels. More specifically, the IHRA argues that "(d)enying the Jewish people their right to selfdetermination, e.g., by claiming that the existence of a State of Israel is a racist endeavor" amounts to anti-Semitism. In other words, the IHRA implies that it is perfectly acceptable for Israel to deny Palestinians, as well as Israelis (including Jews) who identify as Palestinians their right to self-determination, and to exclusively declare Hebrew as Israel's official language (while 
Final-author Version (repaginated) of J. Handmaker (2020) 'Lawfare against academics and the potential of legal mobilization as counterpower', pp. 233-260 in D. Landy, R. Lentin and C. Mccarthy (Eds.) Enforcing Silence: Academic Freedom, Palestine and the Criticism of Israel (London: Zed).

downgrading Arabic), yet it would be anti-Semitic to argue that any of this is racist. Indeed, suggesting that there is a situation of apartheid in Israel would also amount to anti-Semitism according to the IHRA definition.

There has been a lot of discussion regarding the German Bundestag's passing of a non-binding "motion" in May 2019, which appeared to declare that BDS was anti-Semitic. This immediately triggered an open protest by Jewish and Israeli scholars condemning the motion (Oltermann 2019). This notwithstanding, efforts to paint critics of Israel as anti-Semitic are clearly waning. At an event in The Hague that I had organized at my university in October 2018, the respected journalist, scholar and writer Ali Abunimah outlined the consequences of Israel's claim to have a right to exist as a Jewish state as confirmed by the 2018 Nation-State Law (Abunimah 2018). Drawing on illustrations from his earlier book The Battle for Justice in Palestine (2014), Abunimah explained how Israel's right to exist effectively allowed the Israeli government, military and supporters worldwide to pursue a state-sponsored agenda of lawfare. As a practical consequence of this agenda, Abunimah argued that Israel creates legal backing to discriminate, kill and persecute Palestinians.

At the start of his presentation, Abunimah noted that the announcement of the October 2018 event had led to a string of on-line messages and letters by pro-Israel groups, including a letter addressed to my university, invoking the IHRA definition and attempting to smear Abunimah as anti-Semitic (Abunimah 2018). These lawfare efforts to condemn and seek to censor Abunimah were unsuccessful in the Netherlands, where BDS has been confirmed as protected free speech (Lazaroff 2016; Bot 2019). Accordingly, Dutch lawyers advised Abunimah, at no cost, that he could respond by way of legal mobilization and register both 
Final-author Version (repaginated) of J. Handmaker (2020) 'Lawfare against academics and the potential of legal mobilization as counterpower', pp. 233-260 in D. Landy, R. Lentin and C. Mccarthy (Eds.) Enforcing Silence: Academic Freedom, Palestine and the Criticism of Israel (London: Zed).

a civil claim and a criminal complaint in response to the accusations against him, which he ultimately chose not to pursue.

The Hague event illustrated vividly why lawfare and legal mobilization are fundamentally different, the former aimed at suppressing criticism, while the latter is aimed at protecting individual rights, including freedom of expression. In the final part of this chapter I revisit this crucial distinction.

\section{Why should Israel's lawfare be distinguished from legal mobilization?}

Evaluating the crude instrumentalization of law by Israel and its supporters, such as Shurat Hadin and Legal Insurrection confirms the importance of an analytical distinction between lawfare and legal mobilization. They are not the same. In the case of the counter-BDS campaign waged by Israel and its supporters, the legitimacy question has been turned entirely on its head, suggesting that legitimacy is something inherent in the State of Israel itself, and that any actions that challenge this are de facto illegitimate.

From a legal capacity point of view, both the tone and the content of measures taken by the Israeli government have explicitly rejected the role of civic actors to participate in the (international) legal process. Through the anti-BDS law and other measures, notably travel bans as experienced by Barghouti and other advocates, the Israeli government seeks to curtail the work of leading figures in the BDS movement. As part of the battle for legitimacy by Israel and its supporters, arguments have been reinforced by misplaced references to the historical persecution of Jews, which political science professors Mearsheimer and Walt have argued are a key part of a well-organized "Israel lobby" intent on distorting key facts, and obscuring Israel's responsibility for international crimes, including third-state support for Israel's regime (Mearsheimer and Walt 2008). 
Final-author Version (repaginated) of J. Handmaker (2020) 'Lawfare against academics and the potential of legal mobilization as counterpower', pp. 233-260 in D. Landy, R. Lentin and C. Mccarthy (Eds.) Enforcing Silence: Academic Freedom, Palestine and the Criticism of Israel (London: Zed).

Curiously, while the use of structural bias has been clearly evident in the use of law by all parties, the results of such efforts have tended to favor the legal mobilizers rather than those engaged in lawfare. Unlike legal mobilization advocates who reinforce the values underpinning international law, organizations engaged in lawfare have been informed by hollow claims that Israel has faced increasing delegitimization and has been treated unfairly by the United Nations and other international law institutions (Bayefsky 1995). Rather than engage with these international law institutions, lawfare organizations have relied on principles of "necessity," and describe their perceived enemies as operating "outside and against the law threatening the life of the state of Israel" (Kearney 2010, 126). In this way, Israel's military commanders, government lawyers and overseas supporters who are engaged in lawfare reflect Israel's exceptionalist treatment of international law, oppressively instrumentalizing national laws against Palestinians and other BDS advocates that bear little to no relation to international law in general, and human rights law in particular.

Such efforts reaffirm that lawfare can readily serve as a basis for systematic discrimination by elites against particular groups, which adapted to the BDS call has taken the form of an "entrenched system of racial discrimination against ... Arab-Palestinians" (BNC 2005). Hence, the legitimacy of lawfare can be strongly questioned from a legal values standpoint; whereas self-determination, equality and (non-) discrimination are mobilized as fundamental legal values, in contrast to the derisive dismissal of these values by Israel and its supporters.

\section{Conclusions}

Applying the legal mobilization concept to case studies of academics and associations speaking critically of Israel and in solidarity with Palestine vividly reveals how Palestinian and global social 
Final-author Version (repaginated) of J. Handmaker (2020) 'Lawfare against academics and the potential of legal mobilization as counterpower', pp. 233-260 in D. Landy, R. Lentin and C. Mccarthy (Eds.) Enforcing Silence: Academic Freedom, Palestine and the Criticism of Israel (London: Zed).

justice advocates within the BDS movement have mobilized law to pursue a socially progressive agenda. Law has been mobilized as a dynamic means of emancipating people from injustice, as a defense against repressive state measures, to challenge official impunity and as a means to try and hold individuals, states and corporations accountable for (complicity in) violations of international law, and especially human rights.

As I have argued, the BDS call and accompanying global movement is more than merely another form of legal instrumentalism; it is a politically legitimate means of claiming rights and holding violating states and their corporate agents accountable. It is, accordingly, a form of legal mobilization. Furthermore, this form of law-based advocacy should be distinguished from lawfare, which is designed to undermine legal mobilization and indeed undermine the rule of law.

A conclusion that can be drawn here is that the potential of legal mobilization aimed at holding governments accountable to protect human rights has common drivers, both thematically and across different social and political contexts, each of which highlight BDS as a very significant, civic-led form of law-based advocacy. Three of these common drivers deserve specific mention.

First, legal mobilizers have shown how important it is to not only appreciate, but to explain to the rest of the world the social, economic, political and legal context against which BDS take place. This context includes the appalling treatment of Palestinian children, particularly by the Israeli military tribunal system (Parker 2016), the confiscation of Palestinian land to benefit the illegal activities of agricultural companies (Tonutti 2013) and severe restrictions on Palestinians' movement (OCHA 2016), which in turn relate to the state and corporate actors as well as to complicit universities and cultural institutions against whom BDS advocates, including academics, have targetted their efforts. 
Final-author Version (repaginated) of J. Handmaker (2020) 'Lawfare against academics and the potential of legal mobilization as counterpower', pp. 233-260 in D. Landy, R. Lentin and C. Mccarthy (Eds.) Enforcing Silence: Academic Freedom, Palestine and the Criticism of Israel (London: Zed).

Second, the structural bias that conditions BDS advocates utilizing legal mobilization can be reflexively understood (i.e. built into an organization's programming), and critically assessed when academics and other advocates in solidarity with Palestine are making strategic choices to mobilize the law in a particular way, not only through expensive litigation, but also through broad-based movements of civic-led boycotts and divestment.

Finally, the success of strategic legal mobilization interventions is their capacity to go beyond legal-technocratic jargon and invoke multiple strategies, most notably use of the media, that combine legal and other forms of social mobilization to give a human face to, and facilitate a broader and critical engagement with, the issues at stake.

\section{References}

Abdelnour, S. (2013), "Beyond South Africa: Understanding Israeli Apartheid,” Policy Brief, Washington D.C.: Al-Shabaka.

Abunimah, A. (2018), "Introductory Statement" at the seminar Israel's Nation-State Law: A Discussion," The Hague: International Institute of Social Studies.

Abunimah, A. (2014), The Battle for Justice in Palestine, Chicago: Haymarket.

Akram, S., M. Dumper, M. Lynk and I. Scobbie (2011), International Law and the Israeli-Palestinian Conflict, London: Routledge.

Amnesty International (2016), "Israeli government must cease intimidation of human rights defenders, protect them from attacks," London, Index number: MDE 15/3824/2016, 12 April 2016. https://www.amnesty.org/en/documents/mde15/3824/2016/en/ (accessed May 9, 2019)

Ananth, S. (2013), “The Politics of the Palestinian BDS Movement,” Socialism and Democracy, 27(3): 129-143. ASA (2013) "Boycott of Israeli Academic Institutions," Resolution of the American Studies Association, December 16, https://www.theasa.net/about/advocacy/resolutions-actions/resolutions/boycott-israeli-academicinstitutions (accessed May 9, 2019). 
Final-author Version (repaginated) of J. Handmaker (2020) 'Lawfare against academics and the potential of legal mobilization as counterpower', pp. 233-260 in D. Landy, R. Lentin and C. Mccarthy (Eds.) Enforcing Silence: Academic Freedom, Palestine and the Criticism of Israel (London: Zed).

Asmy, B. (2017), "Legal Mobilization in the United States," (pp 16-19) in J. Handmaker, Legal Mobilization in a World Marked By Populism and Crisis: Report of a Colloquium and Public Event, Princeton University, USA, June 12 - 13, 2017.

B.N. (2012), "How the Israeli right conspired to shut down 'lefty' department at BGU" +972 Magazine, published on October 24, 2012, https://972mag.com/who-and-what-are-behind-the-attacks-on-ben-gurion-universityspolitics-and-government-department/58296/ (accessed 10 October 2019).

Barak, A. (2006), "Human Rights in Israel," Israel Law Review, 39(2): 12-34.

Barghouti, O. (2011), Boycott Divestment Sanctions: The Global Struggle for Palestinian Rights, Chicago: Haymarket.

Barnette, J. (2010), "The Goldstone Report: Challenging Israeli Impunity in the International Legal System?" Global Jurist, 10(3): 1-28.

Bayefsky, A. (1995), "Israel and the United Nations' Human Rights Agenda: the inequality of nations large and small," Israel Law Review, 29(3): 424-458.

Ben-Youssef, N. and Tamari, S. (2018) "Enshrining Discrimination: Israel's Nation-State Law" Journal of Palestine Studies, 48(1): 73-87.

Bisharat, G., J. Handmaker, G. Karmi and A. Tartir (2018), "Mobilizing International Law in the Palestinian Struggle for Justice," Global Jurist, 18(3): 1-6.

Bot, M. (2019) "The right to boycott: BDS, law, and politics in a global context", Transnational Legal Theory, https://doi.org/10.1080/20414005.2019.1672134 (accessed 11 October 2019).

BNC (2005), "Palestinian Civil Society Call for BDS," Boycott National Committee, Ramallah, bdsmovement.net/call (accessed May 9, 2019)

Dugard, J. (2018), Confronting Apartheid, Auckland Park: Jacana.

Dugard, J. and J. Reynolds (2013), "Apartheid, international law, and the occupied Palestinian territory," European Journal of International Law, 24(3): 867-913.

Erakat, N. (2019) Justice for Some: Law and the Question of Palestine, Stanford: Stanford University Press.

Falk, R. (2017), Palestine's Horizon: Towards a Just Peace, London: Pluto Press.

Goodman, A. (2017), "BDS leader Omar Barghouti dedicates his Gandhi Peace Award to Palestinian prisoners on hunger strike," Democracy Now, 25 April 2017.

Hager, M. (2016), “Legislating Against BDS: Israel's Current Blitz,” Foreign Policy Journal, February 26, https://www.foreignpolicyjournal.com/2016/02/26/legislating-against-bds-israels-current-blitz/ (accessed 21 April 2017). 
Final-author Version (repaginated) of J. Handmaker (2020) 'Lawfare against academics and the potential of legal mobilization as counterpower', pp. 233-260 in D. Landy, R. Lentin and C. Mccarthy (Eds.) Enforcing Silence: Academic Freedom, Palestine and the Criticism of Israel (London: Zed).

Handmaker, J. (2011), “Beyond Exclusion: Assessing Palestinian Refugees' Struggle for Protection and Recognition and their Potential Contribution to a Peace Settlement," (pp. 197-222) in K. van der Borght, K. Byttebier and C. Mackenzie (eds), Imagining a Shared Future: Perspectives on Law, Conflict and Economic Development in the Middle East, London: Cameron May.

Handmaker, J. (2018), "Liberal Israeli human rights organizations need to learn how to listen," Mondoweiss, June 7, 2018, https://mondoweiss.net/2018/06/liberal-israeli-organizations/ (accessed 10 October 2019).

Handmaker, J. (2019), "Researching legal mobilization and lawfare," ISS Working Paper Series / General Series 641: 1-19, http://hdl.handle.net/1765/115129 (accessed May 9, 2019)

Handmaker, J. and K. Arts (2019), Mobilising International Law for 'Global Justice', Cambridge: Cambridge University Press.

Hauss, B. (2017), “The Right to Boycott is Under Threat,” ACLU, 11 October, https://www.aclu.org/blog/freespeech/right-boycott-under-threat (accessed 26 June 2019).

Hoffman, F. (2003), “Human rights and political liberty,” International Legal Theory, 9(1): 105-22.

IHRA (2016), "Working Definition of Anti-Semitism," International Holocaust Rememberance Alliance Website, https://www.holocaustremembrance.com/working-definition-antisemitism (accessed May 9, 2019).

International Court of Justice (2004), Legal Consequences of the Construction of a Wall in the Occupied Palestinian Territory, The Hague: ICJ.

Kearney, M. (2010), "Lawfare, Legitimacy and Resistance: The Weak and the Law," in XVI Palestine Yearbook of International Law, Leiden: Brill.

Kretzmer, D. (1992), “The New Basic Laws on Human Rights: A Mini-Revolution in Israeli Constitutional Law," Israel Law Review, 26(2): 238-246.

LaHood, M. (2016) “Concerted Attempts to Silence Criticism of Israel in the U.S.” Washington Report on Middle East Affairs, May, https://www.wrmea.org/016-may/panel-3-concerted-attempts-to-silence-criticism-of-israel-inthe-u.s.html (accessed 26 June 2019).

Lazaroff, T. (2016), "In Huge Blow to Israel, Netherlands Declares BDS 'Free Speech,”' The Jerusalem Post, 26 May, https://www.jpost.com/Israel-News/Politics-And-Diplomacy/In-huge-blow-to-Israel-Netherlands-declaresBDS-free-speech-455162 (accessed 26 June 2019).

Legal Insurrection (2018), Website. https://legalinsurrection.com/ (accessed May 9, 2019)

Lis, J. (2011), "Israel Passes Law Banning Calls for Boycott" Haaretz, 11 July, https://www.haaretz.com/1.5026309 (accessed 26 June 2019). 
Final-author Version (repaginated) of J. Handmaker (2020) 'Lawfare against academics and the potential of legal mobilization as counterpower', pp. 233-260 in D. Landy, R. Lentin and C. Mccarthy (Eds.) Enforcing Silence: Academic Freedom, Palestine and the Criticism of Israel (London: Zed).

Mearsheimer, J. and S. Walt (2008), The Israel Lobby and U.S. Foreign Policy, New York: Farrar, Straus and Giroux,.

Merry, S. (2006), "Transnational Human Rights and Local Activism: Mapping the Middle," American Anthropologist, 108(1): 38-51.

OCHA (2016), Fragmented lives: Humanitarian overview 2016, East Jerusalem: United Nations Organization for the Coordination of Humanitarian Affairs, https://www.ochaopt.org/content/fragmented-lives-humanitarianoverview-2016 (accessed 26 June 2019).

Oltermann, P. (2019) "German parliament declares Israel boycott campaign antisemitic," The Guardian, 17 May, https://www.theguardian.com/world/2019/may/17/german-parliament-declares-israel-boycott-campaignantisemitic (accessed 26 June 2019).

Oren, A. (2016), "Israel setting up "dirty tricks" unit to find, spread dirt on BDS groups," Haaretz, 20 June, https://www.haaretz.com/israel-news/.premium-israel-setting-up-dirty-tricks-unit-to-spread-dirt-on-bds-groups1.5397740 (accessed 26 June 2019).

Palestine Legal (2019), “American Studies Association Sued for Academic Boycott”, initially posted on 18 July 2018 and updated on 6 February 2019. https://palestinelegal.org/case-studies/2018/3/8/american-studiesassociation-sued-for-boycott (accessed May 9, 2019)

Pappe, I. (2006), The Ethnic Cleansing of Palestine, Oxford: Oneworld.

Parker, B. (2016), No way to treat a child, Ramallah: Defence for Children International Palestine, https://nwttac.dci-palestine.org/ (accessed 26 June 2019).

Reynolds, J. (2017), Empire, Emergency and International Law, Cambridge: Cambridge University Press.

Roy, S. (2012), "Reconceptualizing the Israeli-Palestinian Conflict: Key Paradigm Shifts" Journal of Palestine Studies, 41(3): 71-91.

Russell Tribunal on Palestine (2011), “Cape Town Session," 5-11 November 2011. http://www.russelltribunalonpalestine.com/en/sessions/south-africa (accessed 9 May 2019)

Safi, M. and Davidson, H. (2014) "Israeli Legal Centre Abandons Lawsuit Against Sydney Academic" The Guardian, 10 July, https://www.theguardian.com/world/2014/jul/10/israeli-legal-centre-abandons-lawsuitagainst-sydney-academic (accessed 26 June 2019).

Samour, N. (2018) "Palestine at Bandung" (pp. 595-616) in Eslava, L., Fakhri, M. and Nesiah, V. (eds.) Bandung, Global History and International Law, Cambridge: Cambridge University Press.

Shurat HaDin (2018), Website of the Israel Law Center https://israellawcenter.org/ (accessed 9 May 2019)

Tamanaha, B. (2005) “The Tension Between Legal Instrumentalism and the Rule of Law”, Syracuse Journal of International Law and Commerce 31(1): 131-154. 
Final-author Version (repaginated) of J. Handmaker (2020) 'Lawfare against academics and the potential of legal mobilization as counterpower', pp. 233-260 in D. Landy, R. Lentin and C. Mccarthy (Eds.) Enforcing Silence: Academic Freedom, Palestine and the Criticism of Israel (London: Zed).

Tonutti, A. (2013), Feasting on the Occupation, Ramallah: Al-Haq, http://www.alhaq.org/publications/Feastingon-the-occupation.pdf (accessed 26 June 2019),

Tucker, J. and Brand, L. (2019), "Public Smear Campaign against Nadera Shalhoub-Kevorkian and Hebrew University's Failure to Protect Her" Committee on Academic Freedom of the Middle East Studies Association, dated March 15, 2019, https://mesana.org/advocacy/committee-on-academic-freedom/2019/03/15/public-smearcampaign-against-nadera-shalhoub-kevorkian-and-hebrew-universitys-failure-to-protect-her $\quad$ (accessed $\quad 10$ October 2019).

Tutu, D. (2012), "Justice requires action to stop subjugation of Palestinians," Tampa Bay Times, April 30, https://www.tampabay.com/opinion/columns/justice-requires-action-to-stop-subjugation-ofpalestinians/1227722 (accessed 26 June 2019).

United Nations (1948), Universal Declaration of Human Rights, 10 December 1948, General Assembly 217 A (III). https://www.refworld.org/docid/3ae6b3712c.html (accessed 9 May 2019)

United Nations (1949), United Nations General Assembly Resolution 194 (III), 11 December, Article 11, https://www.hrw.org/legacy/campaigns/israel/return/un194-rtr.htm (accesssed 26 June 2019).

United Nations (2017), Israeli Practices towards the Palestinian People and the Question of Apartheid, ww.hlrn.org/img/documents/israeli-practices-palestinian-people-apartheid-occupation-executive-summaryenglish.pdf (accessed 26 June 2019).

Winstanley, A. (2017), “Israeli ‘law center' Shurat HaDin admits Mossad ties”, Electronic Intifada, 16 November, https://electronicintifada.net/blogs/asa-winstanley/israeli-law-center-shurat-hadin-admits-mossad-ties (accessed 26 June 2019).

Zonszein, M. (2016), "In Israel, BDS is winning", +972, 28 March, https://972mag.com/in-israel-bds-iswinning/118198/ (accessed 26 June 2019). 